\title{
Instabilities on Alpine temperate glaciers: new insights arising from the numerical modelling of Allalingletscher (Valais, Switzerland)
}

\author{
J. Faillettaz ${ }^{1, *}$, M. Funk ${ }^{1}$, and D. Sornette ${ }^{2}$ \\ ${ }^{1}$ Laboratory of Hydraulics, Hydrology and Glaciology (VAW), ETH Zürich, 8092 Zürich, Switzerland \\ ${ }^{2}$ Department of Management, Technology and Economics, ETH Zürich, 8092 Zürich, Switzerland \\ * now at: Soil and Terrestrial Environmental Physics (STEP), ETH Zürich, 8092 Zürich, Switzerland
}

Correspondence to: J. Faillettaz (jerome.faillettaz@usys.ethz.ch)

Received: 2 May 2012 - Revised: 2 August 2012 - Accepted: 4 August 2012 - Published: 27 September 2012

\begin{abstract}
The processes leading to a glacier instability depend on the thermal properties of the contact between the glacier and its bedrock. Assessing the stability of temperate glacier (i.e. the glacier can slide on its bedrock) remains problematic. In order to scrutinize in more detail the processes governing such "sliding" instabilities, a numerical model designed to investigate gravitational instabilities in heterogeneous media was further developed to account for the presence of water at the interface between the bedrock and the glacier for Allalingletscher. This model made it possible to account for various geometric configurations, interaction between sliding and tension cracking and water flow at the bedrock. We could show that both a critical geometrical configuration of the glacier tongue and the existence of a distributed subglacial drainage network were the main causes of the Allalingletscher catastrophic break-off. Moreover, the analysis of the modelling results diagnosed the phenomenon of recoupling of the glacier to its bed followed by a pulse of subglacial water flow as a potential new precursory sign of the final break-off in 1965. This model casts a gleam of hope for a better understanding of the ultimate rupture process resulting from such glacier sliding instabilities.
\end{abstract}

\section{Introduction}

Gravity-driven instabilities include landslides, mountain collapse, rockfalls, ice mass break-off and snow avalanches. They pose a considerable risk to mountain communities, real estate development, tourist activities and hydro-electric power generation. Gravity-driven instabilities are among the most widespread natural hazard on earth. In the USA and
Europe, they are particularly significant and cause billions of dollars/euros in damage each year (Sidle and Ochiai, 2006). Prediction of such gravity-driven instabilities could be used by policymakers to decide on possible evacuation of the potentially dangerous area. Unfortunately, the accurate prediction of the occurrence of such phenomena remains a somewhat daunting task.

In this context, studying glacier break-off is of particular interest because a glacier consists of a unique natural material (ice) where the interface between ice and bedrock is well defined. This relative simplicity of the system allows us in this study to focus in particular on the rupture processes leading to the initiation of the instability.

Basically three types of "ramp-type" glacier instabilities leading to icefalls may be distinguished, depending on the thermal properties of the contact between glacier and its bedrock (Röthlisberger, 1981; Alean, 1985; Huggel et al., 2004; Faillettaz et al., 2011b): (i) cold glaciers frozen at their bedrock, (ii) polythermal glaciers partly frozen at their bedrock experiencing a localized warming transition between cold to temperate conditions and (iii) temperate glaciers that slide on their bedrock.

The first type of instability mainly affects unbalanced cold hanging glaciers (i.e. snow accumulation is mostly compensated by a break-off; Pralong and Funk, 2006). Based on field data combining surface displacement measurements and seismic activity before break-off, Faillettaz et al. (2008, 2011a) showed that the timing of the event was possibly predictable.

In the other types of glacier instabilities, water plays a key role in the initiation and the development of the instability. Faillettaz et al. (2011b) showed that the onset of the second 


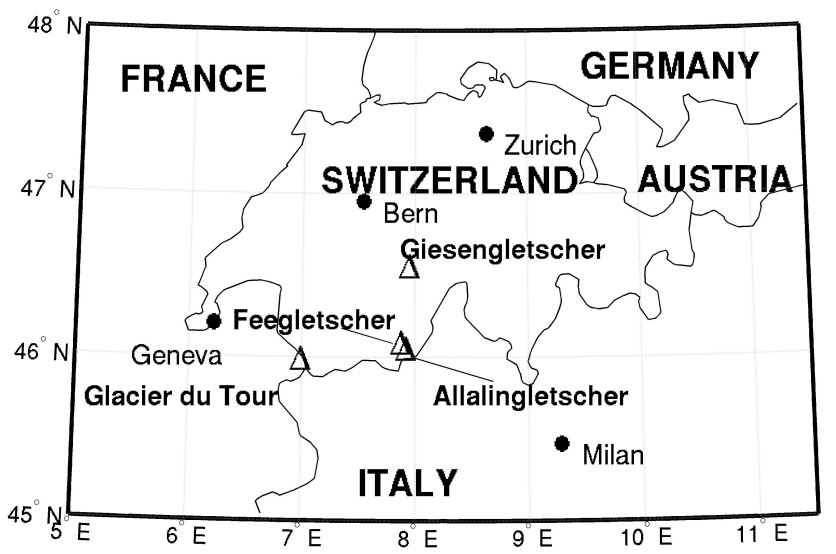

Fig. 1. General map of the location of all glaciers in this study (Allalingletscher, Feegletscher, le Glacier du Tour and Giesengletscher).

type of instability in the case of a polythermal glacier bed could be satisfactorily explained by the presence of meltwater trapped within the glacier that warms the bed/ice interface. This leads to a reduction of the basal resistance at the ice/bed interface which promotes the occurrence of a breakoff event.

The third type of instability (i.e. temperate glacier sliding on their bedrock) is more problematic. In this case, subglacial hydrology plays a major role. Meltwater flowing on the glacier bed may influence the glacier dynamics in two ways: (i) it allows a better lubrication of the bed, and (ii), if water becomes pressurized, an uplift decouples the glacier from its bed.

In the Alps, only few glaciers are known to have given rise to such sliding instabilities in the last century: the Glacier du Tour (Mont Blanc, France) in 1949, the Allalingletscher (Valais, Switzerland) in 1965 and the Feegletscher in 2009. Up to now, the causes of such catastrophic break-offs remain unclear.

The present paper is devoted to the study of such instabilities, taking the Allalingletscher as an example. This glacier is indeed of particular interest because it experienced 2 catastrophic break-offs (in 1965 and 2000) and also because a unique set of data was collected since the first one. To address the open questions on the initiation of the instability, we apply a general numerical model developed to investigate gravity-driven instabilities in heterogeneous media (Faillettaz et al., 2010). This model was already applied successfully to a polythermal glacier becoming partly temperate at its bedrock, i.e. the Altelsgletscher (Faillettaz et al., 2011b). Numerical results indicate that the final instability is driven by a progressive cold-temperate transition at the ice/bed interface. The present study significantly differs from the previous case as here the whole glacier is temperate and can slide on its bedrock. As subglacial water was shown to drive the sliding instabilities, the initial model was extended to account for subglacial water flow at the bedrock.

After describing the Allalingletscher and analyzing available measurements, we apply a general numerical model to this particular gravity-driven instability to assess the causes of the rupture. Numerical results are discussed, and general criteria leading to the instability are presented.

\section{Allalingletscher}

Allalingletscher is located in the Swiss Alps (Valais) near the head of the valley of Saas (Fig. 1). Its terminal tongue is temperate (Röthlisberger, 1981), and its altitude ranges from 2200 to 2800 m. a.s.l. (Fig. 3). The advance of its tongue repeatedly reached and blocked the river Saaser Vispa leading to the formation and the outburst of an ice-dammed lake (Fig. 2). The glacier was mentioned again and again through the centuries, mainly in reference to floods caused during stages of glacier advance, and also when it cut off the path leading to alpine meadows and pass routes to Italy.

The flat area upstream of the south lateral moraine was used for the construction of an artificial reservoir (Fig. 4a). Between 1958 and 1967, an earth dam $120 \mathrm{~m}$ high with a volume of $10^{7} \mathrm{~m}^{3}$ was erected immediately upstream of the south edge of the moraine. A major part of the material used in the construction of the dam was obtained from the lateral moraines, while the flat area between the moraines was used for temporary installations, primarily in connection with the processing of the earth-fill materials.

\subsection{The 1965 and 2000 Break-offs}

On the 30 August 1965, approximately 2 million cubic meters of ice broke off at the terminus of Allalingletscher, moved down a rock slope of some $27^{\circ}$ over the vertical distance of $400 \mathrm{~m}$ and continued for a further $400 \mathrm{~m}$ across the flat bottom of the valley, claiming 88 victims at the Mattmark construction site. An overall view of the area shortly after the ice avalanche is given in Fig. $4 \mathrm{~b}$.

In July 2000, the glacier geometrical configuration was similar to 1965 , and for safety reasons the hazard zone was closed during summer. An ice volume of 1 million cubic meters broke off on 31 July, but did not cause any damage (Fig. 7). After this event, the glacier remained stable, and the terminus stayed more or less at the same altitude.

\subsection{Measurements}

After the 1965 break-off, extensive glaciological measurements were taken (Röthlisberger and Kasser, 1978). They included measurements of cumulative length change of the tongue, thickness along profiles and digital elevation models (Fig. 5). Some surface velocity measurements were also performed the two years following the break-off . A mass balance time series of Allalingletscher was also reconstructed 

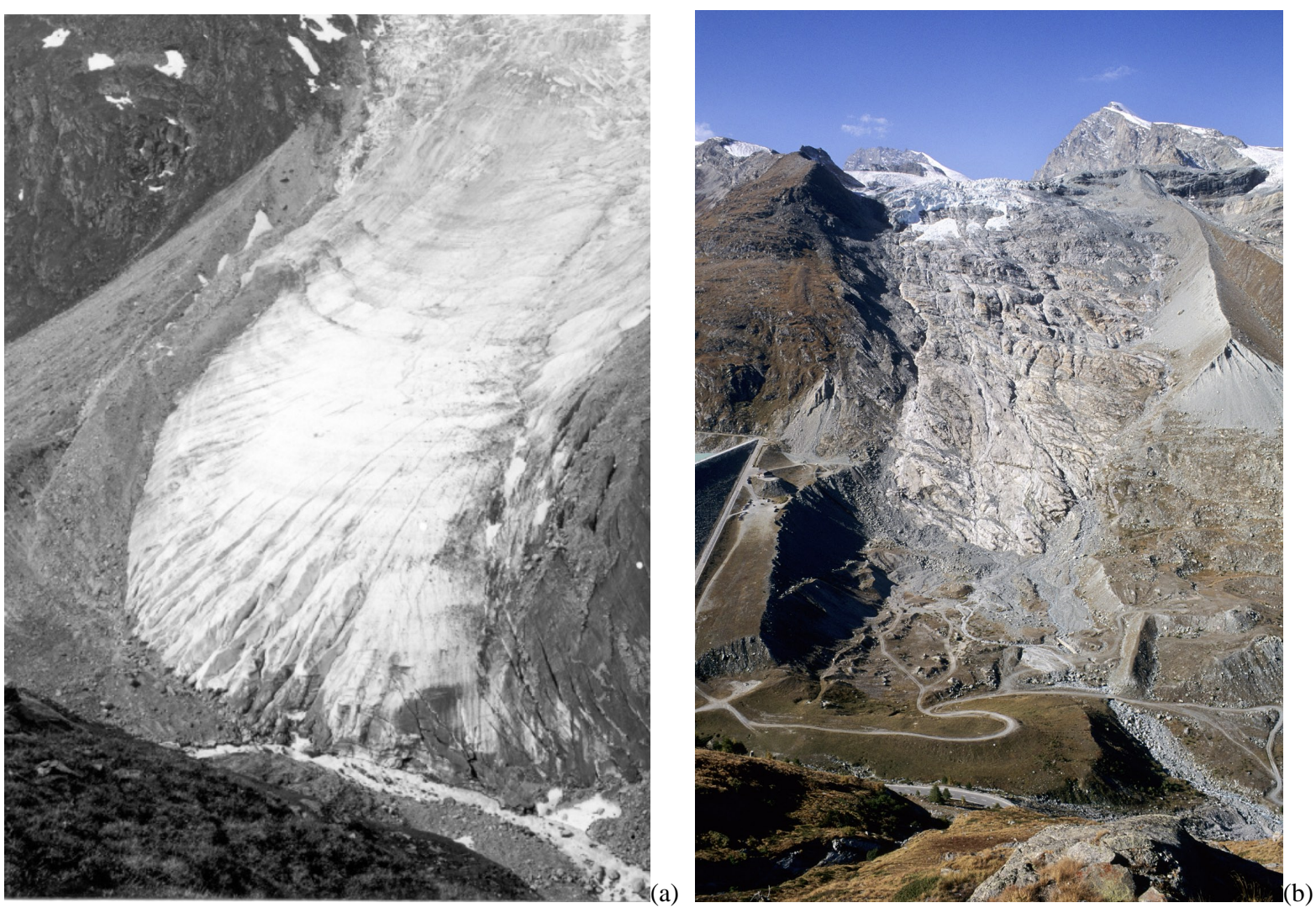

Fig. 2. Allalingletscher (a) in 1916 (O. Lütschg MZA Zurich, 1.7.1916, Archives of the Glacier Commission, Swiss Academy of Sciences) and (b) in 2004 (photo Archive VAW).

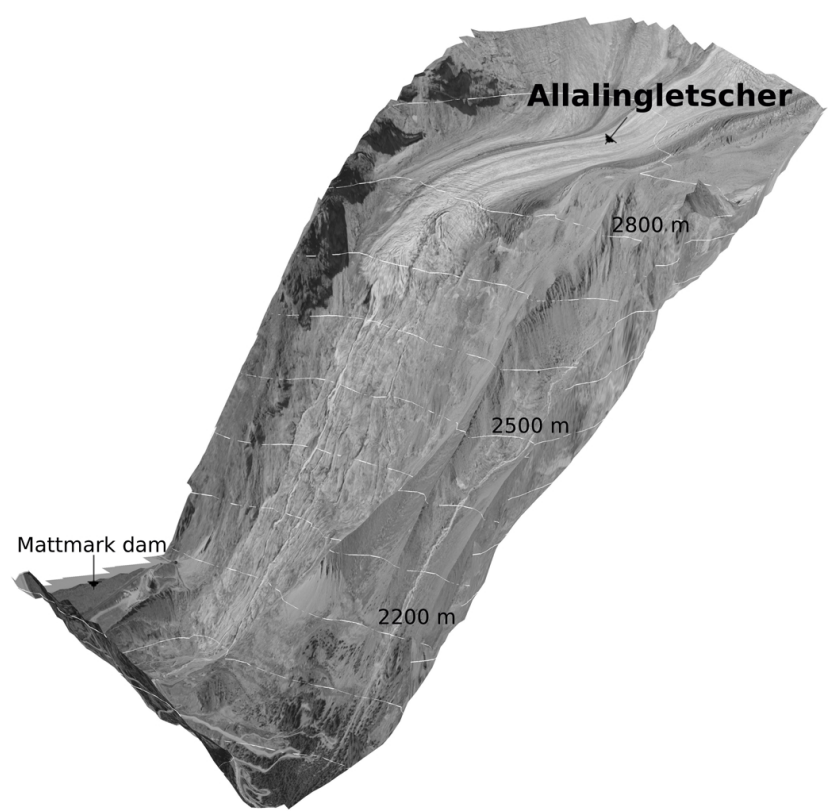

Fig. 3. Detailed topographical map of the Allalingletscher. with the model GERM (Glacier Evolution Runoff Model) developed by Huss et al. (2010). An enhanced version of this model developed by Farinotti et al. (2011) was used to determine daily runoff for the Allalingletscher catchment.

According to available data, the glacier readvanced rapidly after 1965 and recovered its previous geometry $5 \mathrm{yr}$ later. The glacier continued to advance up to 1984 . Since then, the glacier retreated, at an accelerating rate after 1997.

Glaciological investigations (Röthlisberger and Kasser, 1978) showed that the 1965 ice avalanche occurred during a phase of enhanced basal motion (that will be called in the following "active phase") as a result of intensive bed-slip of an even larger mass than the one that broke off on 30 August.

Such seasonal changes in surface velocity have been observed in the years after the catastrophe (Fig. 6), and it is now known that Allalingletscher experienced such active phases regularly every $1-3 \mathrm{yr}$, lasting for 2-3 weeks usually during summer or late autumn. Surface displacement changes during such active phases are similar to the power-law acceleration (Fig. 6) observed before the instabilities of unbalanced glaciers (Röthlisberger, 1981; Faillettaz et al., 2008). Röthlisberger and Kasser (1978) pointed out a possible link with subglacial water flow as these active phases have always begun during the melt season and, perhaps even more 

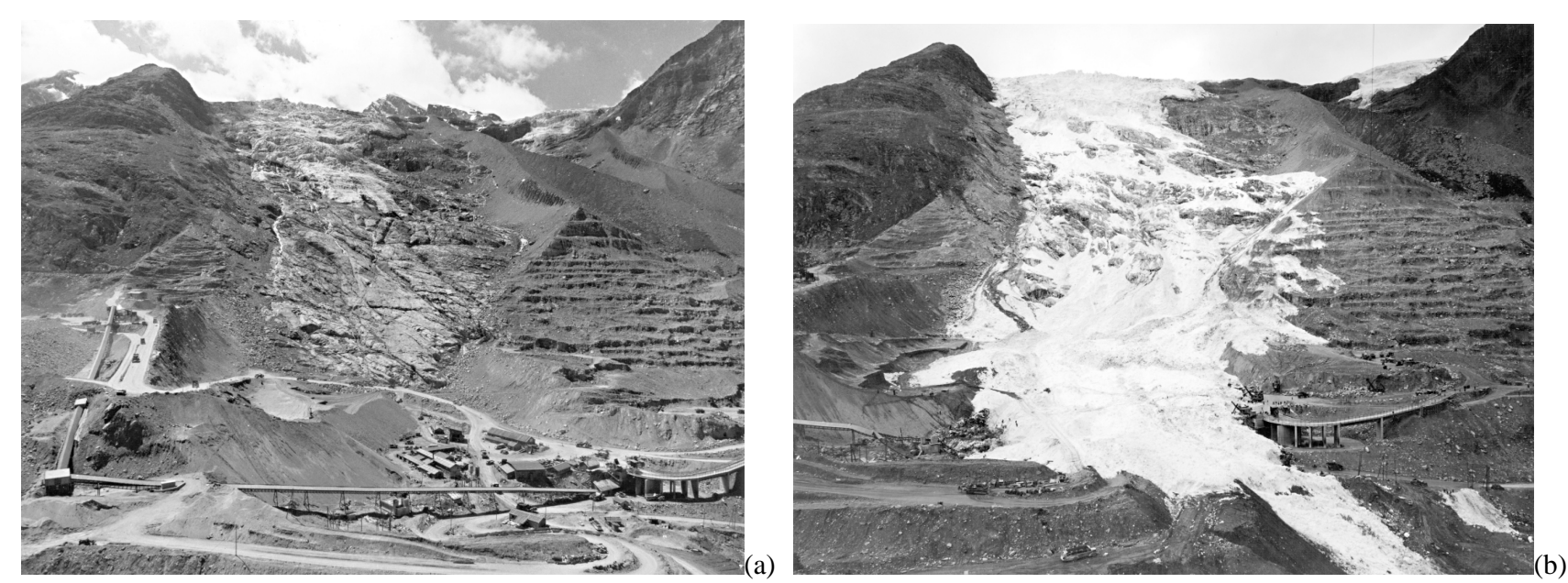

Fig. 4. Allalingletscher (a) before and (b) after the Mattmark catastrophe, 30 August 1965: Breaking-off of $2 \mathrm{million}^{3}$ of ice (P. Kasser, Photo Archive VAW).

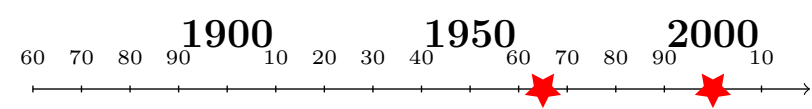

Cumulative length

$1860 \quad 1880$

2010

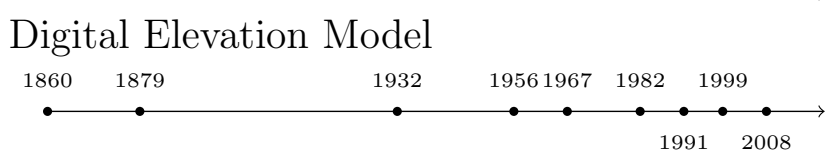

\section{Reconstructed runoff} $1860 \quad 1899$

2010

Fig. 5. Timeline of the available data for Allalingletscher. Stars indicate the occurrence of the break-offs.

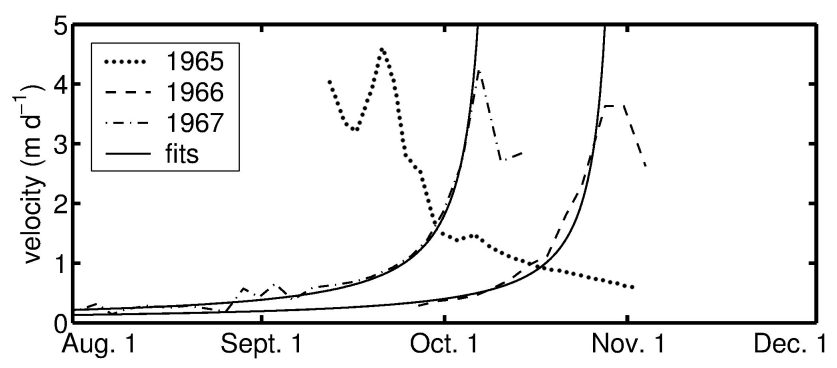

Fig. 6. Evolution of the surface velocity of Allalingletscher tongue between 1965 and 1967. Solid black lines are the fitted velocities with a power law.

significantly, have stopped at the beginning of the winter. This seems to indicate that meltwater plays a major role in the processes triggering the active phases. However, except in 1965 and 2000, the active phases ceased suddenly without formation of any major ice avalanche. Active phases are therefore assumed to only constitute a necessary (but not sufficient) precondition for the break-off to occur.

Although it seemed that this particular condition was necessary for the whole lower part of the ice mass to slide off, it does not explain why the large ice avalanche occurred in 1965 and not during other active phases either before or after this date. A certain topography of the bed, combined with an critical mass distribution, is believed to have played a major role in the catastrophe.

To investigate the causes of this instability in more detail, we reanalyzed the event by applying a new numerical model designed for describing natural gravity-driven instabilities (Faillettaz et al., 2010). This model allows us to test the different hypotheses proposed previously and to explore the possible causes of the observed break-off events.

\section{Numerical modelling}

\subsection{Model}

\subsubsection{Short model description}

The model takes into account the progressive maturation of a heterogeneous mass towards a gravity-driven instability, characterized by the competition between frictional sliding and tension cracking. A complete model description can be found in Faillettaz et al. (2010). The glacier is discretized into a regular two-dimensional array of ice blocks that can slide on the given bedrock topography. Each block interacts with its neighbours via elastic-brittle bonds. A realistic state- and rate-dependent friction law derived from Dieterich (1994) was used for describing the block-bed interaction (Faillettaz et al., 2011b). We modelled the evolution of the inner material properties of the ice and its progressive damage eventually leading to failure, by means of a stress corrosion law 


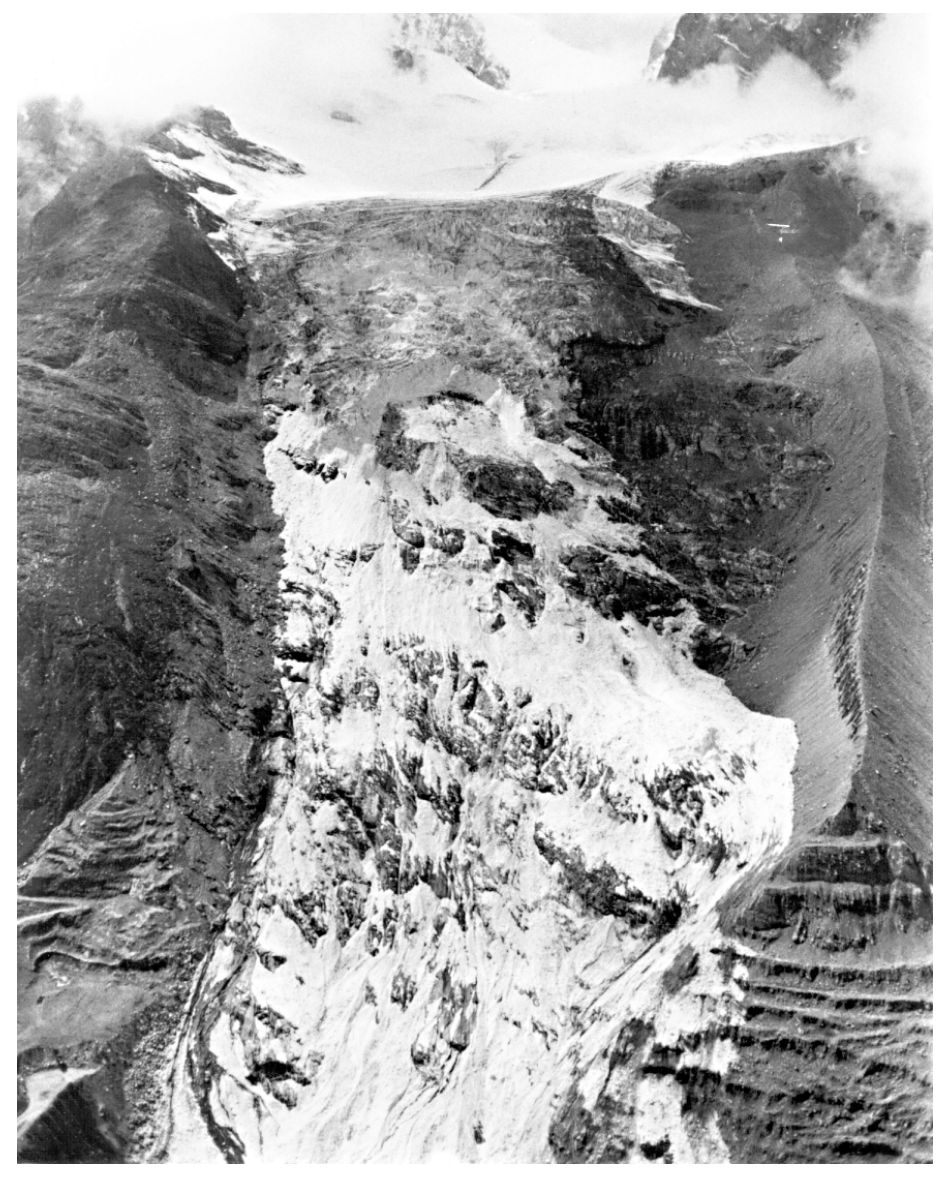

1965

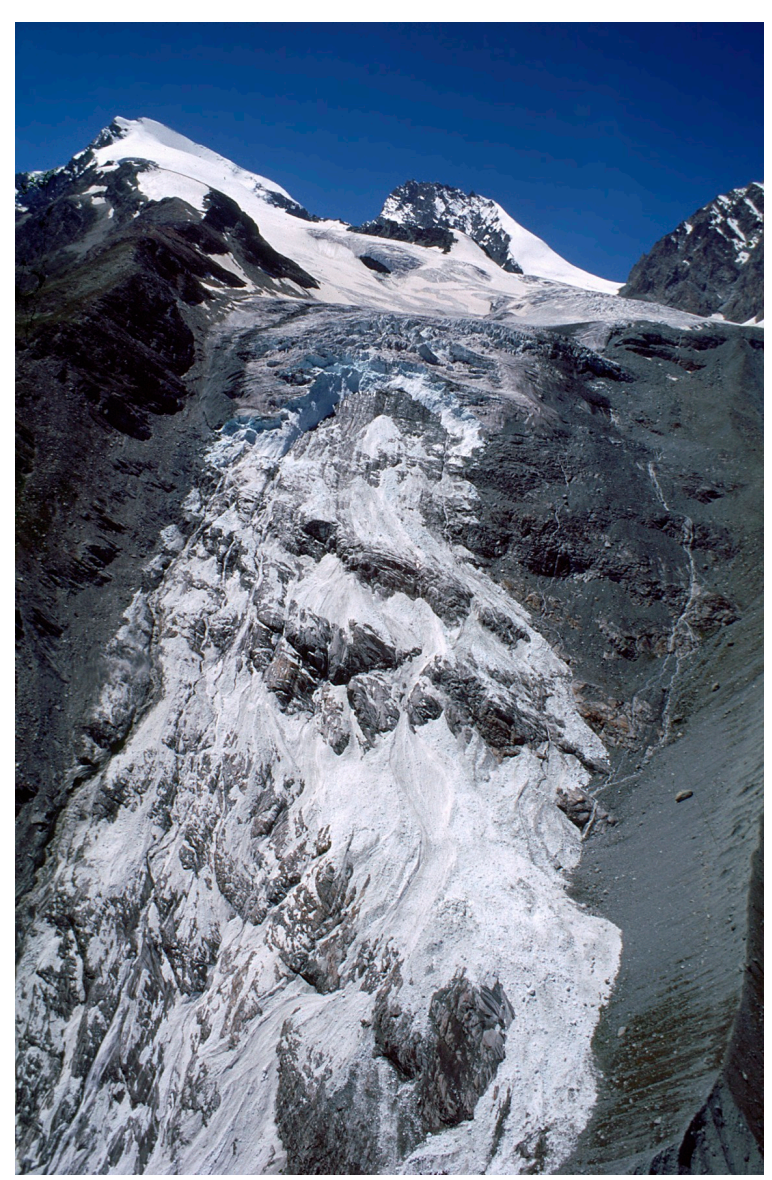

2000

Fig. 7. Allalingletscher after the 1965 event ( 2 million $\mathrm{m}^{3}$ of ice on 30 August 1965) and after the 2000 event ( $1 \mathrm{million}^{3}$ on $\left.31 \mathrm{July} 2000\right)$. (Photo H. Röthlisberger (left) and F. Funk-Salamí (right)).

governing the rupture of the bond. The application of this model, especially the friction and creep laws, to a glacier is discussed in detail in Faillettaz et al. (2011b)

In order to reproduce cracking and dynamic effects, all equations of motion (including inertia) for each block are solved simultaneously.

\subsubsection{Extension of Faillettaz et al. (2010) model: accounting for the effect of subglacial water flow}

In our initial model, the effect of subglacial water flow on basal motion was not included. Basal processes play a key role in the dynamical behaviour of steep glacier tongues (see Sect. 2.2). Meltwater flow at the glacier bed influences the glacier dynamics (Bell, 2008) in two ways: (i) it lubricates the bed, and, (ii) if water becomes pressurized, the glacier can be partially decoupled from its bed. The lubrication of the bedrock leading to a progressive decrease of the icebedrock frictional resistance is modelled by decreasing the friction coefficient $\mu_{0}$ (Faillettaz et al., 2011b). The following assumptions are made:
1. The friction coefficient depends on the subglacial water pressure (Schweizer and Iken, 1992; Jay-Allemand et al., 2011).

2. The subglacial water pressure and discharge variations at the daily time scale are similar (Boulton et al., 2007).

3. As a consequence of the two previously mentioned assumptions, the change in the friction coefficient can be assumed to be proportional to the discharge of subglacial water flow.

4. The ice thickness does not vary drastically along the glacier tongue. Hence, glacier surface and glacier bed topographies are similar. It follows that the gradient of the hydraulic potential, and therefore the flow path of water is directly determined by the bedrock topography (Flowers and Clarke, 1999).

As a first step, the amount of basal water flowing under each block has to be evaluated. We used a toolbox developed by Schwanghart and Kuhn (2010) to assess the subglacial drainage network with a DEM of the glacier bed. DEMs are 


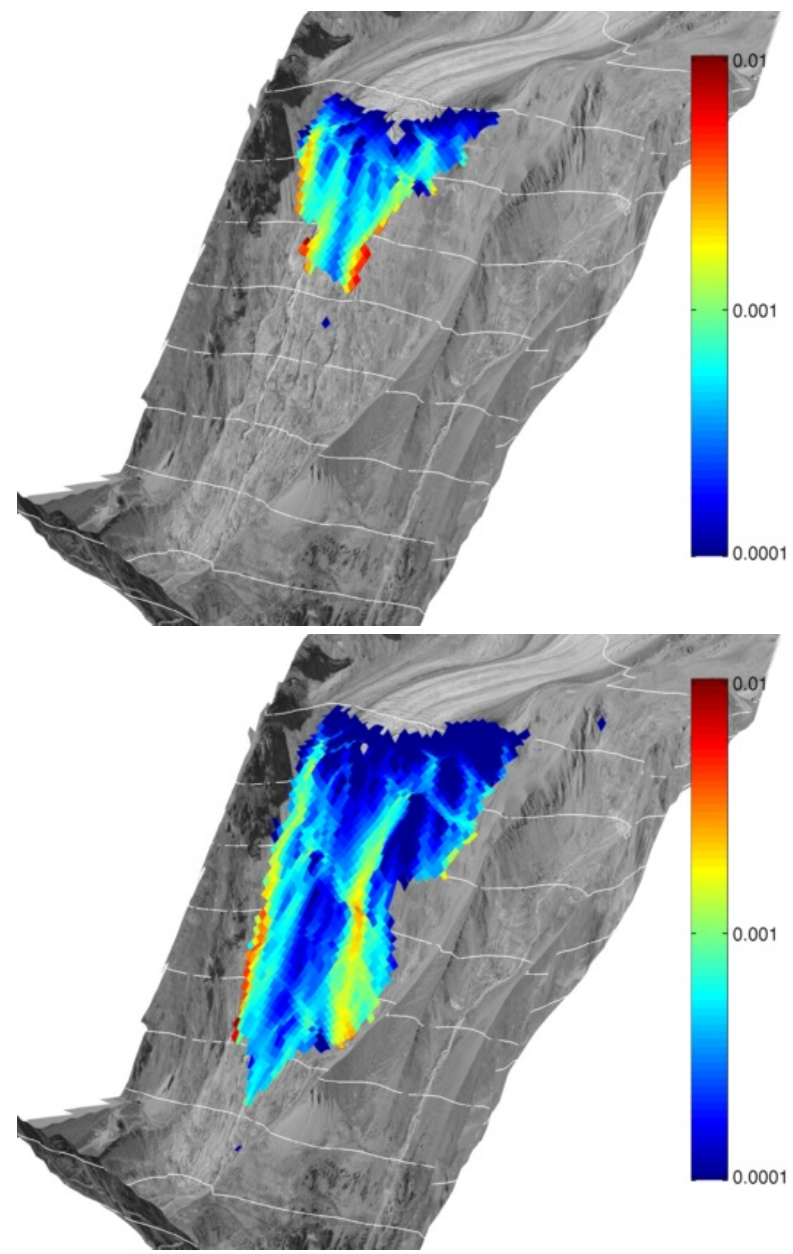

(a)

(b)

Fig. 8. Relative contribution of each block to the total subglacial water discharge $\left(\mathrm{Z}_{\mathrm{ev}}\right)$ for 1999 (a) and 1982 (b). Red zones indicate where discharge of subglacial water is larger.

most commonly represented as rectangular grids where an elevation value is assigned to each cell. Two steps are needed to evaluate the basal water flow under each cell of the DEM. First, the flow direction is evaluated via a transfer matrix $M$. Elements in $M$ contain the relative amount of discharge $M_{i j}$ transferred from one cell $i$ to its downward neighbours with the index $j$. In this process, the transfer ratios are proportional to the downward slope to the respective neighbour. Second, by counting the number of cells draining in each grid cell, the upstream contributing drainage area is calculated. Finally, this toolbox gives the relative contribution from each cell of the DEM to the global runoff at the outlet. The amount of water flowing through a particular cell of the DEM is then obtained by multiplying the total runoff at the outlet by its relative contribution. Results are shown in Fig. 8.

In a second step, the friction coefficient is adapted according to the basal water discharge under each block with the simplified following relationship:

$\mu_{o}(i, j)=\mu_{1}-Z_{\mathrm{ev}}(i, j) \cdot Q \cdot c_{p}$

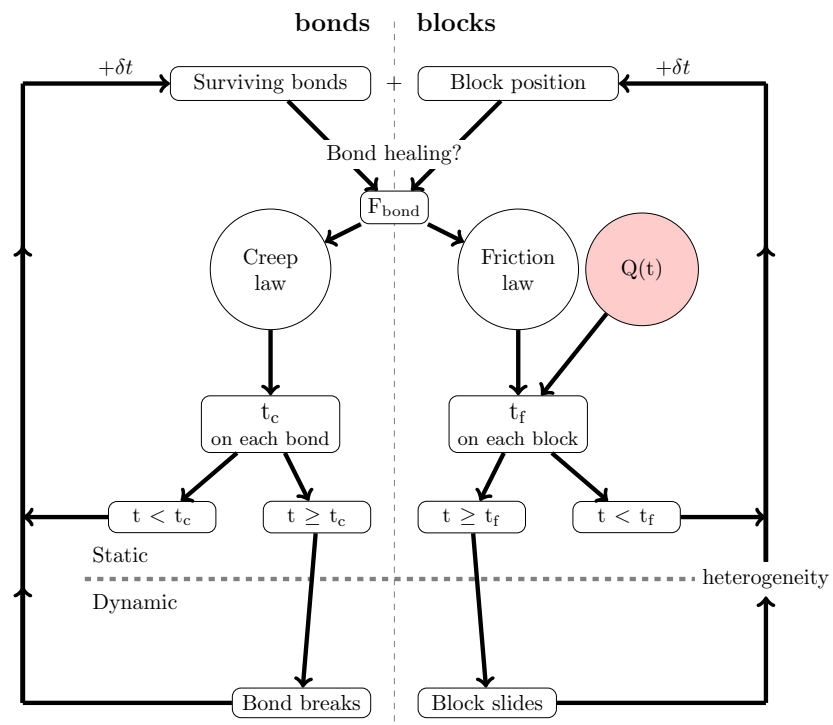

Fig. 9. Schematic flowchart of the spring-block model modified from Faillettaz et al. (2010) accounting for subglacial water flow.

where $\mu_{o}$ is the friction coefficient of a given block $(i, j), \mu_{1}$ a constant friction coefficient, $Z_{\mathrm{ev}}(i, j)$ is the relative contribution of the block, $Q$ is the daily runoff at the glacier terminus and $c_{p}$ is a scaling parameter quantifying the relative influence of the basal water on the friction coefficient. In this way, the friction coefficient of a block is assumed to decrease when the local subglacial water discharge (and therefore the local subglacial water pressure) is increasing.

\subsubsection{New algorithm accounting for subglacial basal water flow}

The different steps describing how the instability is modelled are plotted in Fig. 9 (for more details, see Faillettaz et al., 2010). Two phases have to be distinguished:

(i) a quasi-static (quiescent) phase corresponding to the nucleation of block sliding and damage accumulation in bonds, and

(ii) a dynamical (active) phase corresponding to the sliding phase of the blocks and the failure of bonds.

The new algorithm takes into account the subglacial water flow. At each time step of the run, the friction coefficient under each block is modified according to the local subglacial discharge. $\mu_{0}$ is evaluated with Eq. (1) based on the runoff at the outlet given by the model of Farinotti et al. (2011) and the matrix $Z_{\mathrm{ev}}$ calculated from the DEM of the bedrock topography. 
Table 1. Numerical values of parameters used in our simulations.

\begin{tabular}{cccccc}
\hline \multicolumn{5}{c}{ Friction parameters } \\
$\mathrm{A}$ & $\theta_{0}$ & $\mu_{0}$ \\
- & $\mathrm{d}$ & - & & \\
0.1 & 100 & 0.8 & & \\
\hline \multicolumn{7}{c}{ Creep parameters } \\
$E$ & $\beta$ & $C \sim 1 / K$ & $\xi$ & $e_{01}$ & $e_{02}$ \\
$\mathrm{~Pa}$ & $\mathrm{~Pa}^{-1}$ & $s$ & - & - & - \\
$10^{9}$ & $10^{-7}$ & $10^{3}$ & 10 & 0.003 & 0.003 \\
\hline \multicolumn{7}{c}{ Runoff parameters } \\
$\mu_{1}$ & $c_{p}$ & & \\
0.8 & 6 & \\
\hline
\end{tabular}

\subsubsection{Parameters}

First, the geometric input parameters have to be considered for modelling Allalingletscher. The glacier is discretized into a system of parallelepipedic blocks. As shown in Sect. 2.2, the spatial extension of the glacier tongue substantially changed during the last century. Digital elevation models (DEM) of the tongue for different years are available (see Fig. 5). In this study, we performed simulations for two extreme cases: one where the extension of the glacier tongue was at a maximum (i.e. in 1982) and the other where the glacier broke off (i.e. in 2000). Since the glacier has completely retreated from the steep part, a detailed bedrock topography of the former glacier tongue could be obtained by a photogrammetric processing of recent aerial photographs (2008).

To obtain a realistic description of the damage and fragmentation process that may develop in the ice mass, a sufficiently large number of blocks is needed. As a compromise between reasonable sampling and numerical speed, $20 \times 20 \mathrm{~m}$ blocks were considered. Other simulations with different block sizes were performed, showing similar results. The spatial extensions of the glacier under each block, as well as the block heights in 1999 and 1982, are given by the respective DEMs. The slope of the bedrock under each block is given by the 2008 DEM.

Second, the friction $\left(A\right.$ and $\left.\theta_{0}\right)$ and the creep $(\beta, \mathrm{C}, \xi$ and $e$ ) parameters have to be determined. Following Faillettaz et al. (2011b) who successfully modelled the development of the glacier instability of the Altelsgletscher, the same set of parameters was taken (see Table 1).

Third, the runoff parameter $c_{p}$ in Eq. (1), which quantifies the relative influence of the runoff on the friction parameters, had to be tuned in such a way that the 2000 break-off could be qualitatively reproduced. We arbitrarily chose $c_{p}=6$ as this parameter seemed to qualitatively reproduce the shape and the time occurrence of the 2000 break-off.

\subsection{Numerical results}

The aim of the numerical simulations is to better understand the development of a glacier sliding instability, considering Allalingletscher as an example. In particular, we intend to provide answers to the following questions:

- Why did the glacier break off only in 1965 and 2000?

- Does the glacier geometry play a role in the occurrence of the break-off?

- What effect does subglacial water have on the glacier dynamics and on the break-off?

- Does the subglacial drainage network efficiency play a role in the onset of instability?

- Is it possible to find precursory signs of the break-off?

- Would it be possible to predict the break-off?

To address these different issues, different simulations were performed to investigate the relative influence of the glacier geometry and the temporal fluctuations of the subglacial water flow on the onset of the instability.

First, a qualitative approach is adopted in which two different glacier geometries (a stable and an unstable one) are simulated with constant basal properties. In this way, the development of the instability could be investigated independently of the influence of the subglacial water flow.

Second, another qualitative test was performed to assess whether a channelized subglacial network could lead to an instability.

Finally, simulations accounting for the glacier geometry and the temporal fluctuation of the subglacial water flow of two different years were undertaken.

\subsubsection{Influence of the glacier geometry on the instability}

To investigate the contribution of the glacier geometry on the onset of the instability, we performed numerical simulations on two different glacier geometries in the year 2000 (when a break-off occurred) and the year 1982 (when an active phase could be evidenced without break-off). Friction coefficients under each block are set to a constant. In this way, the effect of the temporal fluctuations of the subglacial water flow is not considered, allowing the investigation of the effect of the glacier geometry alone on the initiation and development of the instability. Table 1 summarizes the parameters used in our simulations.

Figure 10 shows the results of simulations for both geometries of 2000 and 1982 with the same creep and friction parameters. As the terminal part of the glacier lies on an average slope of $30^{\circ}$, we set the friction coefficient to be a bit lower than its mean slope, i.e. $\mu_{0}=0.5$.

It was possible to reproduce the initiation of the instability with this set of parameters. As expected, the blocks situated 


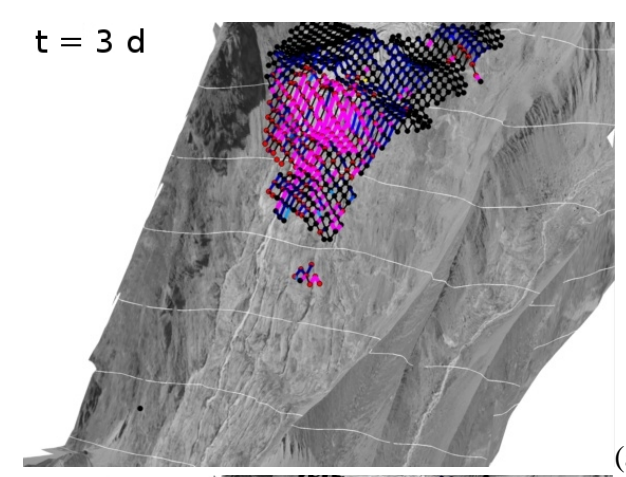

(a1)
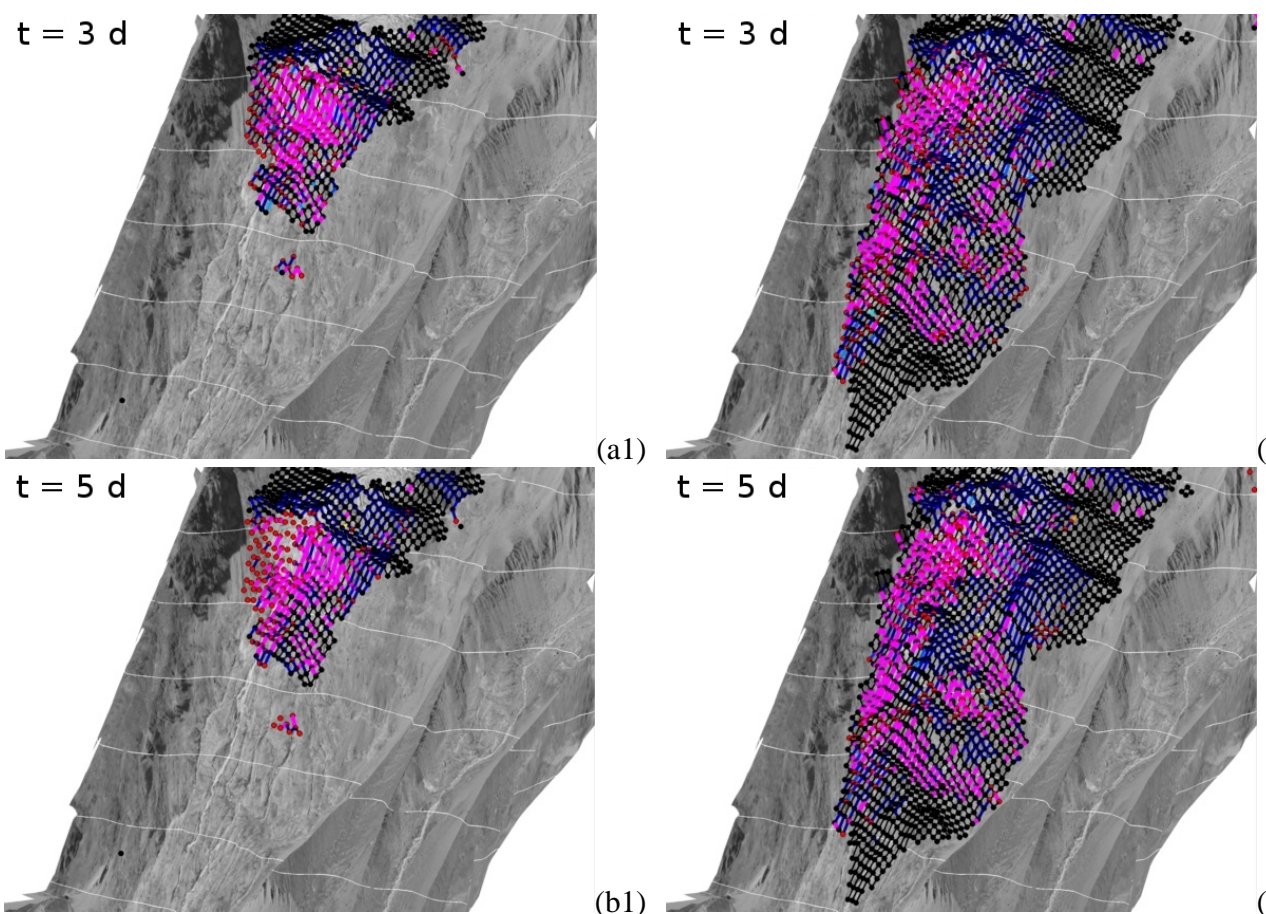

(a2)

(b1)

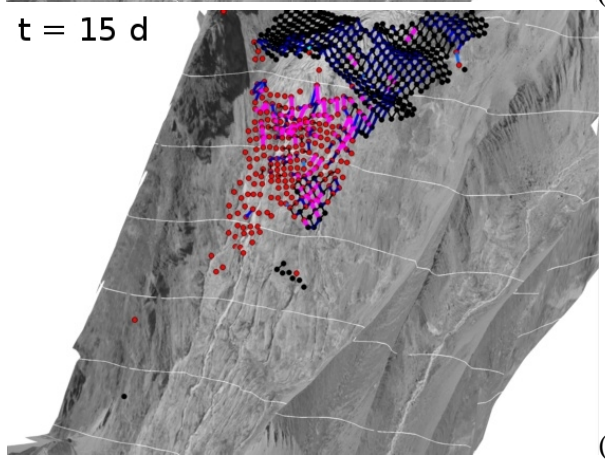

(c1)

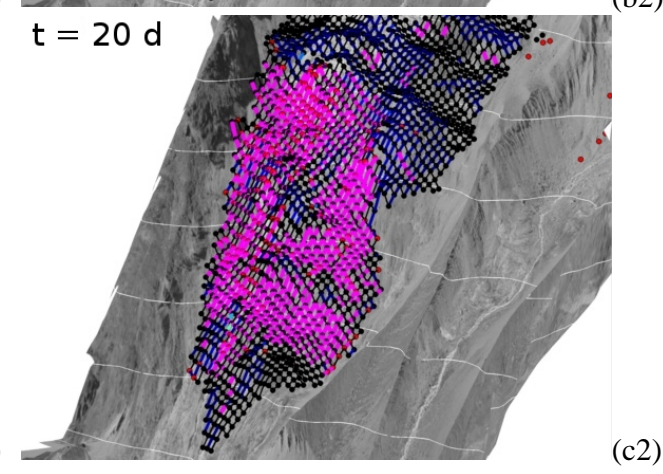

Fig. 10. Snapshots describing the rupture progression for the glacier geometry in the years 2000 (left) and 1982 (right), with a constant friction coefficient. For the sake of simplicity, blocks are represented as small circles where the black coloured circles indicate static blocks and the red ones the sliding blocks. The colour of a bond evolves from blue to red as the stress changes from larger than the critical stress $s^{\star}$ (Faillettaz et al., 2010, i.e. the minimum stress such that the material will eventually fail) to close to rupture. Bonds where stress is lower than $s^{\star}$ are drawn in thin black. Bonds in compression are coloured magenta.
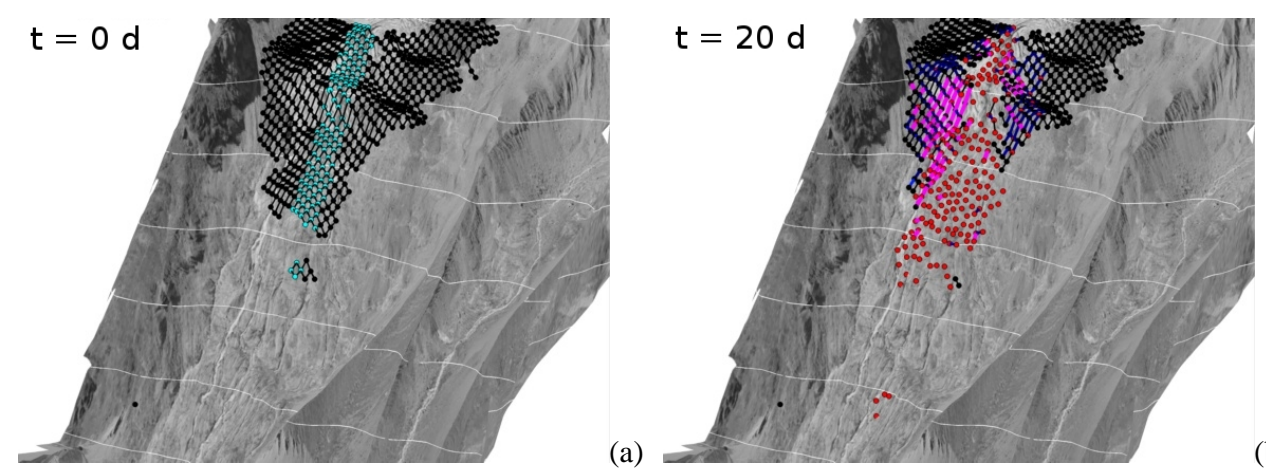

Fig. 11. (a) Blue blocks indicate where the friction coefficient was decreased. (b) Snapshot at the end of the run (same legend as in Fig. 10) where the instability results in a localized break-off with a triangular shape. 


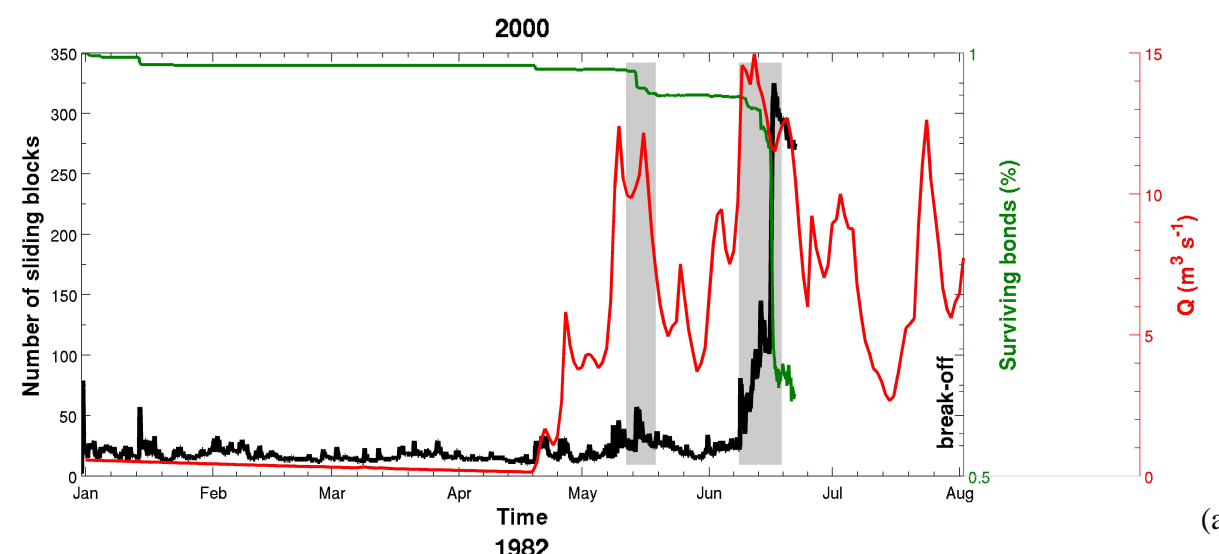

(a)

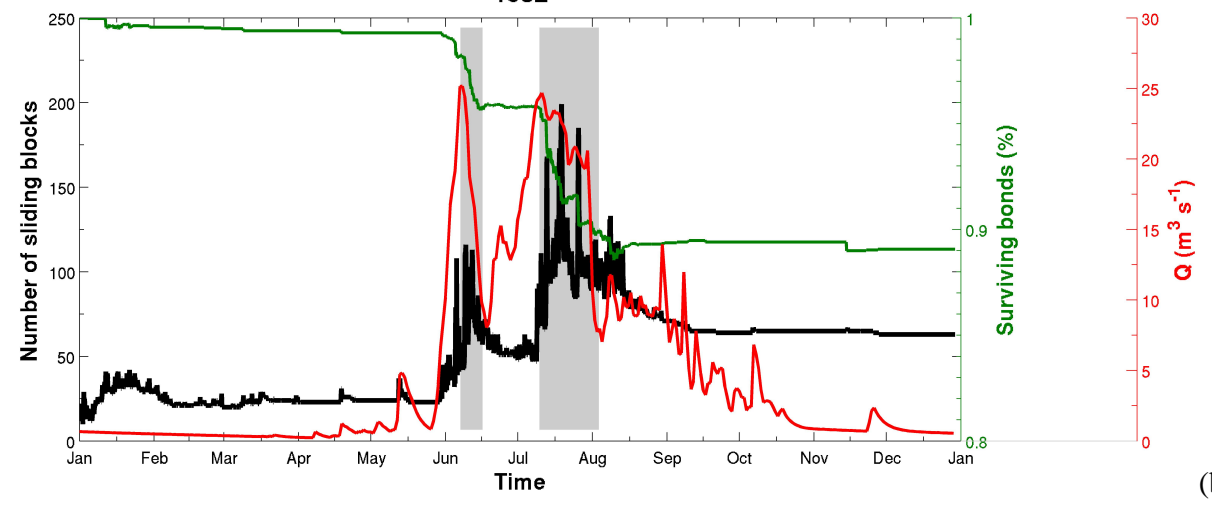

(b)

Fig. 12. Runoff, number of sliding blocks and surviving bonds as a function of time for the situation in 2000 (a) and 1982 (b). Gray zones indicate periods during which intensive fragmentation occurs.

in the steepest part started to slide first, inducing a zone with high tension stresses where the slope changed. Then, blocks located downstream started to slide creating a compression zone directly downstream of this process zone (Fig. 10b1, b2). This compression zone grew as the instability developed. In the case of the 1982 geometry, the compression zone continued to propagate downwards and reached the terminus where the glacier was less steep. The whole glacier was then supported by the lower part of the tongue, which stabilized the glacier and stopped the development of the instability (Fig. 10c2). By contrast, in the case of the 2000 geometry, the compression zone reached the terminus where the slope was still large. Nothing supported the advance of the glacier, resulting in a global break-off of the tongue (Fig. 10c1). Note that the qualitative shape of the 2000 break-off was reproduced in this case.

Therefore, the geometrical configuration of the glacier tongue plays a role in the development of the instability, independently of subglacial water flow, in agreement with the critical slope concept (Röthlisberger, 1981; Alean, 1985; Huggel et al., 2004). In the case of Allalingletscher, the glacier tongue is stabilized if the glacier terminus is located downstream the position of 1965 , as the slope near the terminus is lower.

\subsubsection{Role of subglacial drainage network topology}

In Sect. 2.2, we pointed out that the presence of water seems to play a role in the initiation and the development of the instability. The subglacial water and drainage network play a role in the initiation and the development of the instability. In general, the subglacial drainage network topology could range from channelized to distributed. To investigate at least qualitatively the influence of the drainage network topology on the instabilities, we performed simulations where the friction coefficient was decreased locally, in a band roughly situated at the center of the glacier (Fig. 11a). The band width was set arbitrarily at 3 blocks, i.e. $60 \mathrm{~m}$. This allowed the effect of the subglacial water flow to be reproduced in a restricted area, by decreasing the friction coefficient as a function of discharge (see Sect. 3.1.2).

After the development of the upper crevasse at the slope break, the instability developed, leading to a localized breakoff with a triangular shape (Fig. 11b). Moreover, to obtain such a rupture, the friction coefficient had to be set to a very low value $\left(\mu_{0}=0.2\right)$, indicating a stronger stability in the case of a channelized network than with a distributed one. A channelized network could not reproduce, even qualitatively, the break-off event of the year 2000 . 


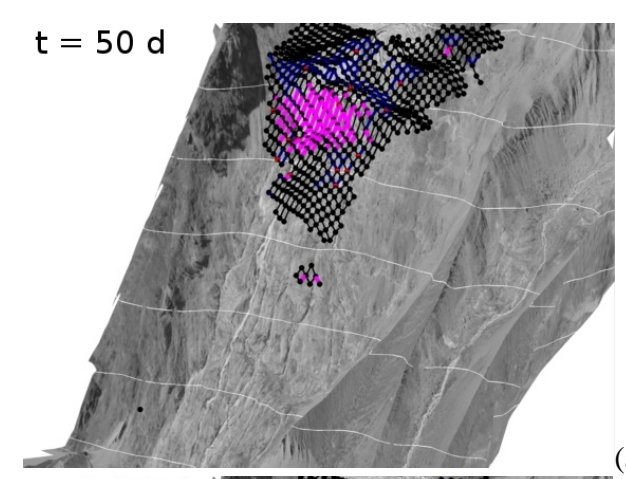

(a1)

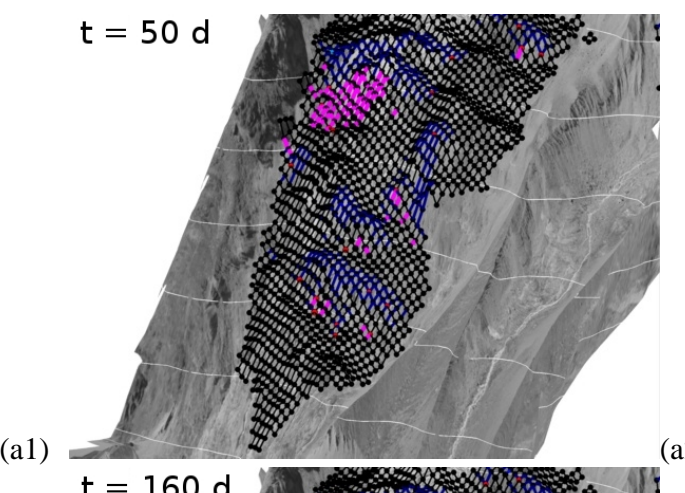

(a2)

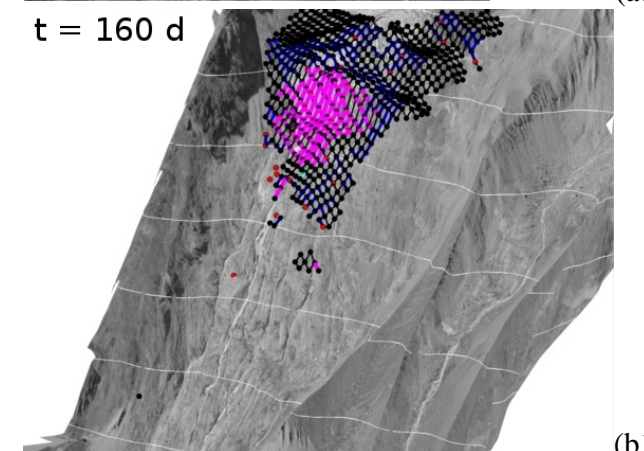

(b1)

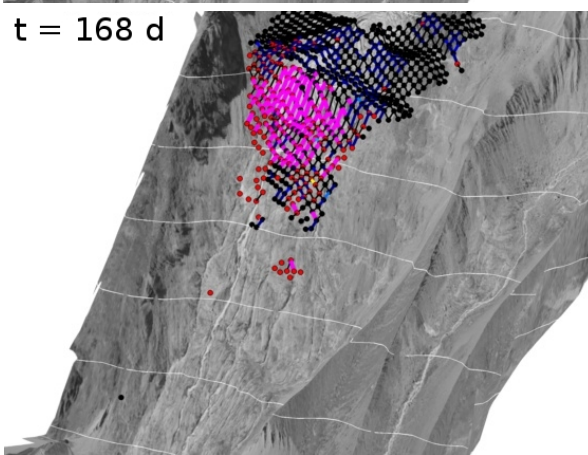

(c1)

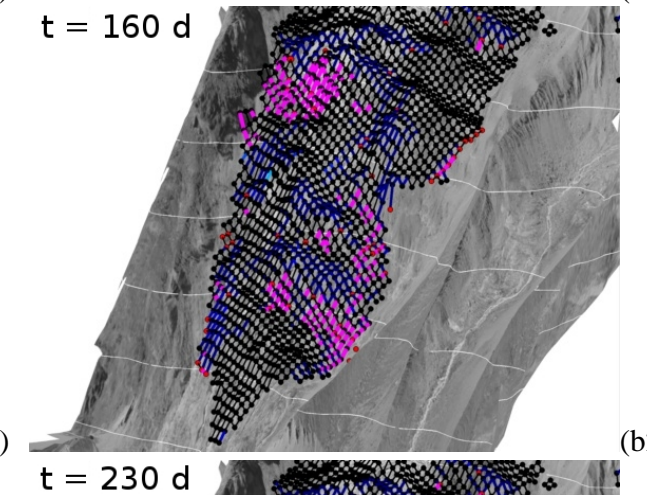

(b2)

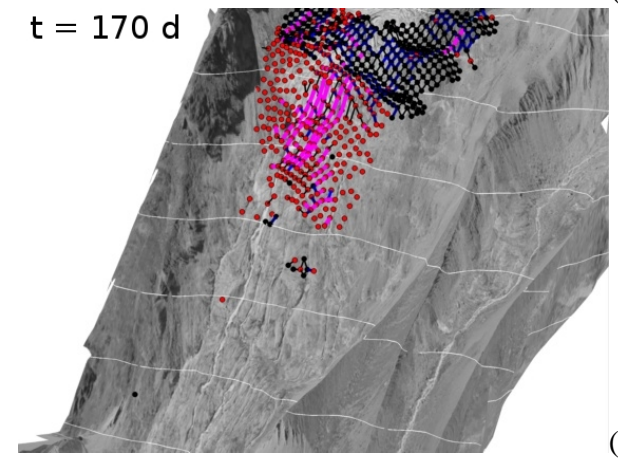

(d1)

(d2)

Fig. 13. Snapshots describing the rupture progression and sliding instability in the block lattice for the years 2000 (left) and 1982 (right), with friction coefficients evolving with subglacial flow (see Eq. 1). For the sake of simplicity, blocks are represented as small circles where the black coloured circles indicate static blocks and the red ones the sliding blocks. The colour of a bond evolves from blue to red as the stress changes from larger than $s^{\star}$ (Faillettaz et al., 2010) to close to rupture. Bonds where stress is lower than $s^{\star}$ are drawn in thin black. Bonds in compression are coloured magenta.

\subsubsection{Distributed subglacial drainage network}

We performed two runs with the same creep and friction parameters, but for two different years (1982 and 2000). For these $2 \mathrm{yr}$, the modelled daily runoff at the outlet of the glacier was available (red lines in Fig. 12). The model allowed the water under each block to be redistributed according to Eq. (1) (Fig. 8). A large set of $c_{p}$ parameters was tested 


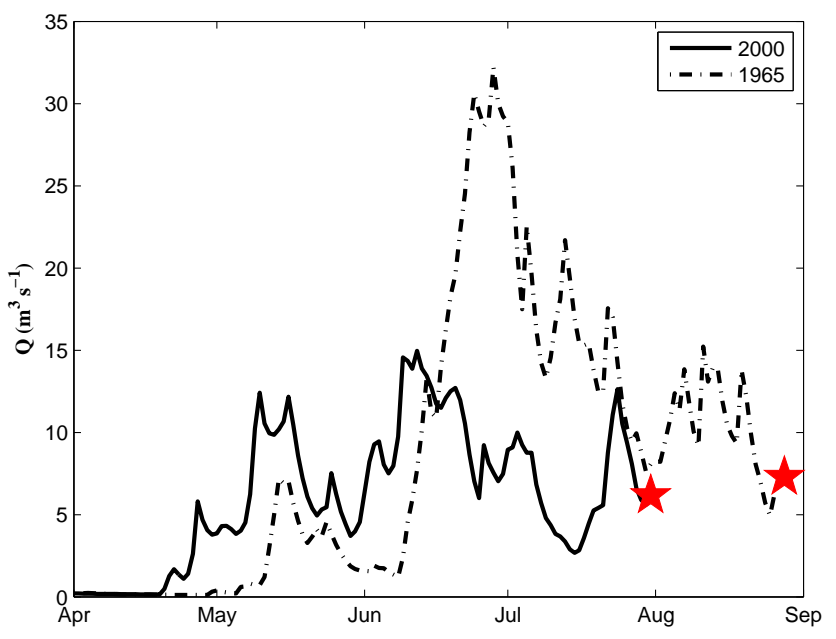

Fig. 14. Modelled runoff in 1965 and 2000. Stars indicate the occurrence of the break-offs. In both cases, break-offs occurred after a period of runoff decrease.

ranging from 1 to 10 (see Eq. 1). In the following, we show results of simulations using $c_{p}=6$, which seems to be a reasonable value that enabled both the 2000 break-off and the 1982 stable cases to be reproduced accurately.

Figure 13 shows the evolution of the instability for the years 2000 and 1982. In 2000, after the opening of the crown crevasse and the formation of a compressive zone at the glacier tongue (Fig. 13a1), the glacier entered into a quiescent regime. Even the runoff increase in May did not affect the dynamics of the glacier tongue (Figs. 13b1 and 12a). Suddenly, after 165 days of simulation (in mid-June), the tongue started to become unstable, resulting in a fragmentation process that propagated over the whole tongue in a few days (Figs. 13c1, d1 and 12a). We stopped the simulation when the glacier tongue was completely disaggregated. In 1982, the situation was different as the tongue extension was larger (Fig. 13a2). The compression zone propagated downstream until it reached the lowest glacier tongue, where the bed slope was decreasing (Fig. 13b2). An increase in the number of sliding blocks can be noticed between mid-July and early September (Figs. 13c2 and 12b), indicating an ongoing active phase. Interestingly, this active phase is not directly correlated with the runoff magnitude, as it dropped in August in the course of the ongoing active phase. It also appears that, once triggered, the active phase needs some time to be stopped (Figs. 13d2 and 12b).

\subsection{Interpretations}

It turns out that the model provides new insights into the maturation process of the instability. Numerical results suggest the following sequence of ongoing processes:

1. A critical geometrical configuration of the glacier tongue is needed where the glacier terminus rests on a steep slope (see Sect. 3.2.1).

2. The subglacial drainage network has to be distributed (see Sect. 3.2.2).

3. The onset of the active phase is induced by an increase in subglacial water flow (see Sect. 3.2.3).

4. The initiation of the fracturing process starts in a period of decreasing runoff, i.e. during a rapid recoupling phase of the glacier onto its bedrock. During this phase, an intensive fracturing of the glacier tongue is initiated.

5. A catastrophic break-off requires the combination of two opposing phenomena: first, the glacier needs to be in an active phase with a strongly enhanced basal motion, and second, this active phase must be stopped abruptly with a rapid recoupling of the glacier to its bed.

The likelihood of this process chain can be verified on the basis of observations during the years 2000 and 1965 when the glacier broke off. It appears that, for both years, one month before the rupture, the runoff drastically increased, which could have led to an active phase (Fig. 14). During the 6 days prior to the break-off, the runoff dropped from 13 to $5 \mathrm{~m}^{3} \mathrm{~s}^{-1}$ in 2000 and from 14 to $5 \mathrm{~m}^{3} \mathrm{~s}^{-1}$ in 1965 (Fig. 14). It appears that the process chain leading to the final breakoffs in 1965 and 2000, inferred by the numerical results, is confirmed by these observations.

It also appears that both catastrophic break-off events occurred when the runoff increased after a period of reduced subglacial water flow, especially in 1965 . This suggests that, once the glacier is recoupled onto its bedrock, an additional pulse of water is needed to trigger the instability. A possible interpretation could be that, as the subglacial channel stability is controlled by the balance between creep closure and melting of ice walls generated by the heat dissipated by the flowing water, a persistent runoff decrease would have led to a progressive channel closure and therefore to a reduction in the efficiency of the drainage network. Then, this runoff pulse led to an increase in basal water pressure and a decrease in basal resistance which could have initiated the catastrophic break-off event.

These are new insights into the processes responsible for the instabilities occurring at Allalingletscher. Are all these findings valid only for this particular glacier or is it possible to generalize them? To answer this question and validate these findings, we analyzed other observed sliding instabilities in the light of these new results. 

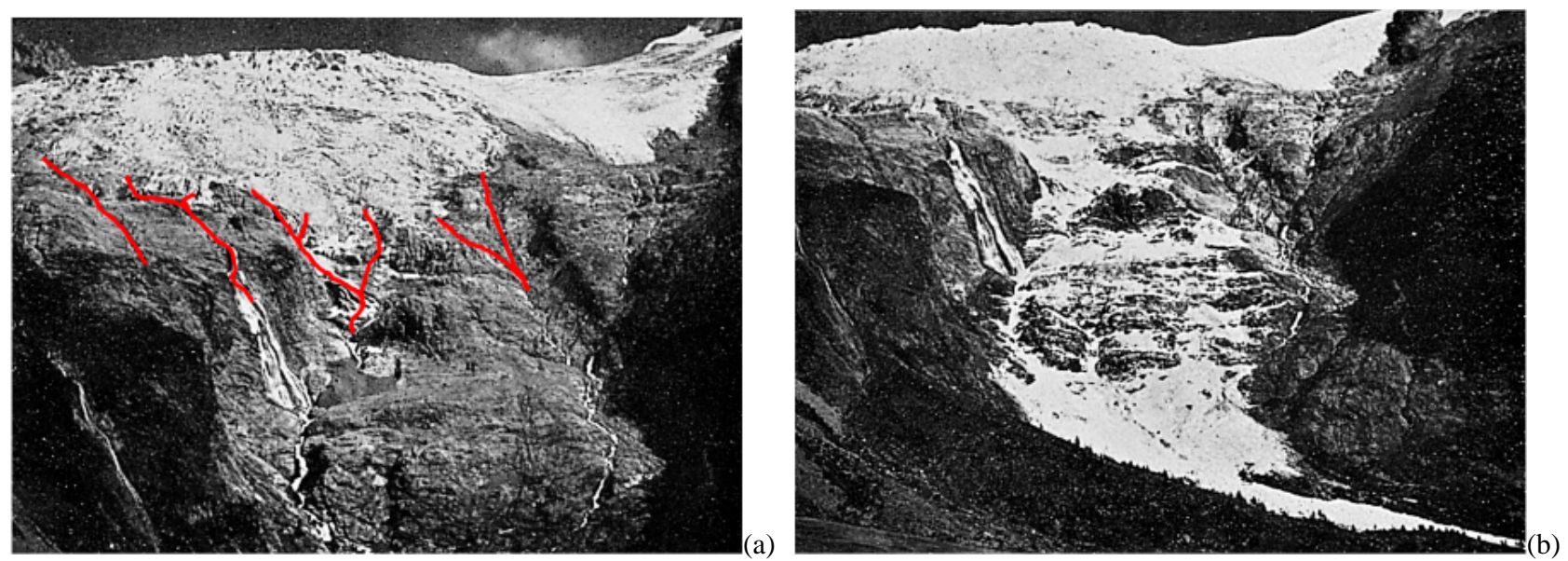

Fig. 15. Glacier du Tour in 1949 (a) before the break-off (the possible drainage network highlighted in red) (b) after the break-off, after Glaister (1951).
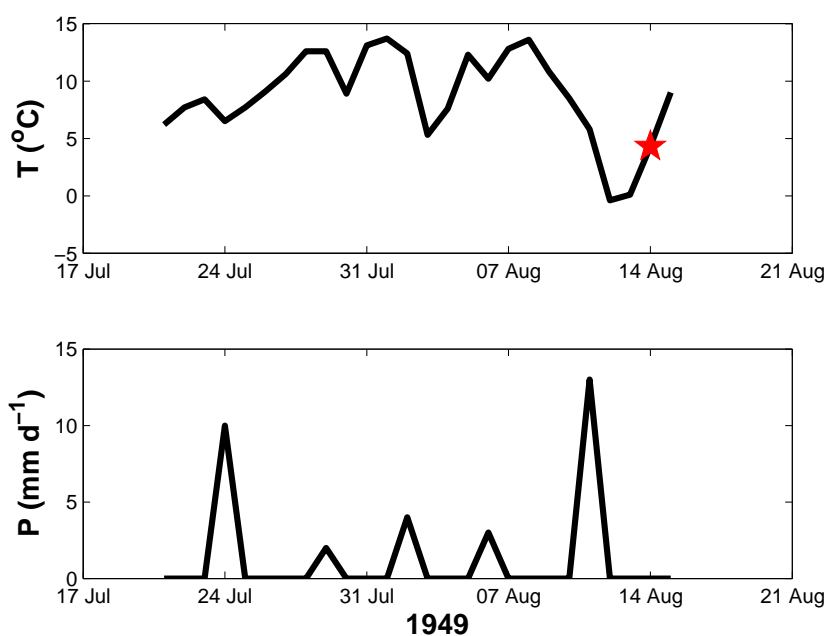

Fig. 16. Temperature and precipitation in summer 1949 at the Col du Grand Saint Bernard (2472 m a.s.1.), located about $20 \mathrm{~km}$ west of the Glacier du Tour. The break-off is indicated by a red star.

\section{Application to other observed sliding instabilities}

\subsection{Break-off of the Glacier du Tour, 1949}

The terminal tongue of the Glacier du Tour (Mont Blanc, France) broke off on 14 August 1949. Estimation of the volume of the break-off ranges from 0.5 to 2 million cubic meters (Glaister, 1951). At that time, the glacier geometry was similar to Allalingletscher in 1965. The upper part of the glacier was lying on a flat zone, whereas its tongue ended on very steep terrain (about 40 degrees) that was not able to support the glacier tongue. At that time, the glacier tongue was also in a critical geometrical configuration. Moreover, different subglacial streams emerging from the glacier could be distinguished, indicating a distributed
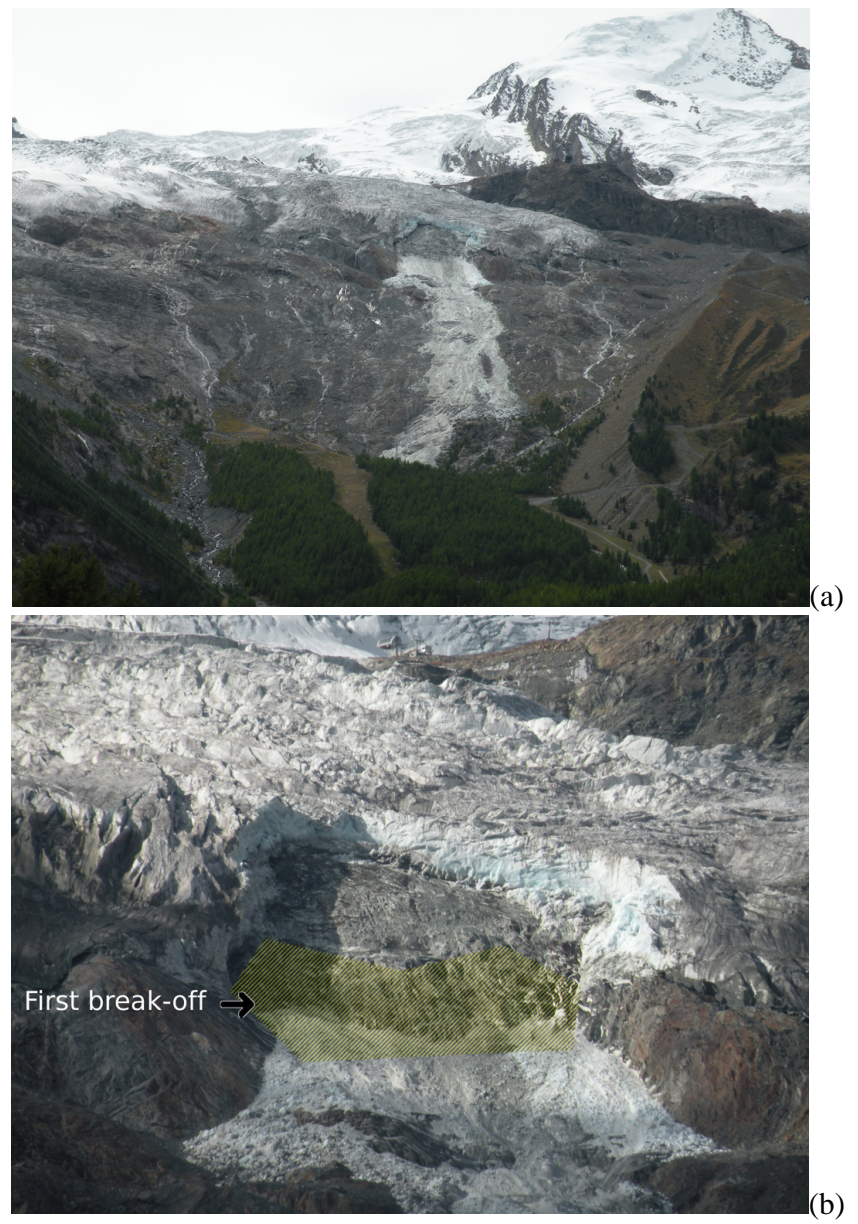

Fig. 17. (a) General view of the Feegletscher after the break-off event in 2009. (b) Closer view of the break-off. Yellow zone indicates the extension of the first break-off event (Photo Archive VAW). 

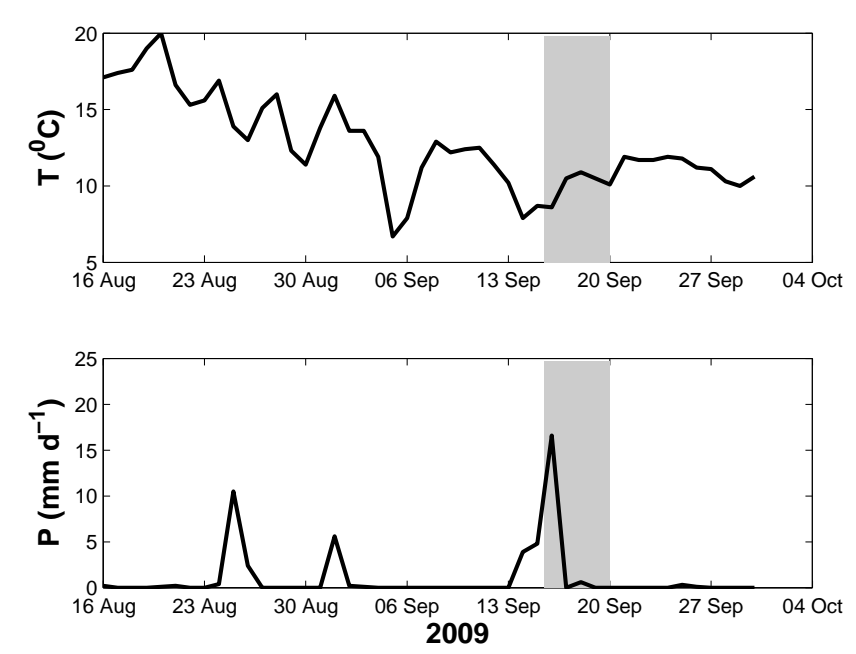

Fig. 18. Temperature and precipitation in summer 2009 at Zermatt, located approximately $15 \mathrm{~km}$ west of the Feegletscher. The breakoff events are indicated by a gray zone.

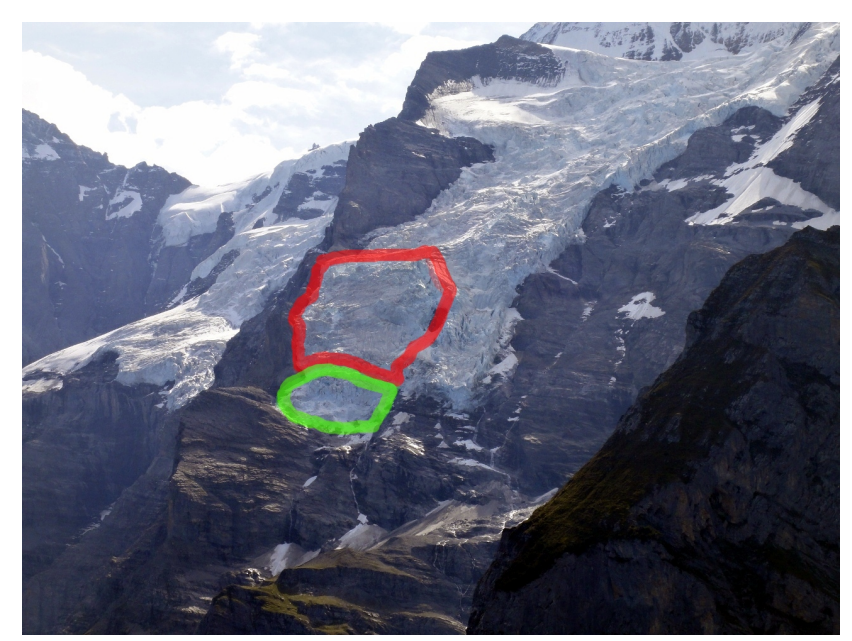

Fig. 19. Situation of Giesengletscher in 2011 from north. Green zone indicates the stable part of the tongue, in red the possible unstable zone.

subglacial drainage network (see Fig. 15). The two main criteria for a break-off in the case of a sliding instability were likely to be met. Meteorological conditions prevailing in this area were analyzed (Fig. 16) to infer a runoff history prior to the break-off event. The temperature time series indicates that, in the month preceding the break-off, temperatures were high (about $10^{\circ} \mathrm{C}$ at $2472 \mathrm{~m}$ ). Five days before the break-off, the temperatures dropped from 14 to $0^{\circ} \mathrm{C}$. Subglacial runoff magnitude should have decreased drastically during this period. This confirms that the recoupling of the glacier on its bed played a decisive role in the break-off event.

Moreover, two days before the break-off event, the temperature started to increase and a precipitation event occurred. This could have led to an increase (pulse) of subglacial wa- ter flow. These facts also confirm that an additional pulse is needed to trigger the final catastrophic event.

\subsection{Feegletscher, 2009}

The Feegletscher is located just few kilometers away from Allalingletscher in the Saas Valley near Saas Fe in the Swiss Alps (Valais). It ranges between 4200 and 1900 m. a.s.l. The terminal part of its tongue broke off twice, on 15 September and 19 September 2009. The total ice volume affected by these break-off events was estimated between 300000 and $400000 \mathrm{~m}^{3}$ (Fig. 17). After the first break-off, a large crevasse spanned the glacier and the whole isolated part finally broke off 4 days later.

Figure 17a indicates that, where the break-off occurred, the tongue was relatively steep, indicating a possible critical geometrical configuration. Moreover, a lot of water streams emerged from the glacier terminus and, as the bedrock is relatively smooth, a distributed subglacial drainage network can be expected.

The two prerequisite conditions were thus fulfilled. The break-off occurred in late summer, as in the cases of Allalingletscher and the Glacier du Tour. Subglacial water flow seemed also to have played a role in the instability. Figure 18 indicates that air temperature was high in August, inducing a large amount of meltwater. During this period, the glacier should have been in an active phase. Later, air temperature decreased from 16 to $6^{\circ} \mathrm{C}$ between 1 September and 5 September, then increased to $13^{\circ} \mathrm{C}$ for a few days and decreased again to $8^{\circ} \mathrm{C}$ from 8 September to 14 September. Although less evident than in the other cases, temperature decreased by $8{ }^{\circ} \mathrm{C}$ in the two weeks preceding the break-off event. This could have led to a substantial decrease in the meltwater input, and therefore to a period with reduced subglacial water flow. A relatively low-efficient drainage network seemed to have prevailed before the rupture also in this case. Rainfall was recorded two days before the event (Fig. 18) which could have led to a sudden increase in subglacial water flow. This observation confirms that a subglacial water pulse preceded by a period of reduced subglacial water flow favoured the instability.

\subsection{Climatic changes and glacier instabilities: example of the Giesengletscher (Swiss Alps)}

In a more general context, climate change may affect the stability of glaciers. Although some glaciers will disappear, thus eliminating the associated hazard, some others that were stable up to now could enter into a critical regime leading to an instability. As a general glacier retreat in the Alps is observed, the geometry of some glaciers might potentially evolve towards a critical situation. As an example, Giesengletscher in the Bernese Alps (Switzerland) would be a suitable candidate for a future catastrophic break-off. The terminus of Giesengletscher is located at about $2500 \mathrm{~m}$. a.s.1. In 
2008, a crevasse spanning the whole glacier was observed indicating an ongoing active phase on the steepest part (about 35 degrees, Fig. 19). The situation is nevertheless not critical yet, as the glacier terminus is resting on a moderate slope, which stabilizes the glacier tongue (green zone in Fig. 19). Moreover, its bedrock is likely smooth, so that the drainage network is expected to be distributed. Except for the geometrical configuration of the tongue, all conditions for the glacier to break off are fulfilled, indicating that the disappearance of the supporting glacier terminus, as a result of a possible future glacier retreat, could lead to a critical situation.

\section{Conclusions}

Instabilities occurring on temperate glacier tongues are strongly affected by the subglacial hydrology: infiltrated meltwater may indeed cause (i) a lubrication of the bed and (ii) a decrease in the effective pressure at the glacier bed and consequently, a decrease in basal friction. Available data from Allalingletscher (Valais, Switzerland) indicate that the glacier tongue experienced an active phase for 2-3 weeks in summer in most years between 1965-2000 with strongly enhanced basal motion. This glacier broke off twice, in 1965 and 2000. In order to scrutinize in more detail the processes governing the sliding instabilities, a numerical model developed to investigate gravitational instabilities in heterogeneous media was applied to Allalingletscher. This modified spring-block model makes it possible to account for various geometrical configurations of the glacier and also for interactions between basal sliding and tension cracking. The impact of subglacial water flow on basal motion was included in the model.

Our results confirm that basically three preliminary conditions have to be fulfilled for a break-off to occur in the case of a sliding instability: (i) a critical geometrical configuration of the glacier tongue is needed, where the glacier terminus rests on a steep slope; (ii) the glacier has to experience an "active phase" during which basal motion drastically increases; (iii) the subglacial drainage network has to be distributed. Moreover, our modelling results diagnose two other possible precursory signs of the impeding break-off event: (i) a period of diminished subglacial water flow is needed to reduce the efficiency of the drainage network and promote fracturing processes; (ii) finally, a pulse of subglacial water flow triggers the catastrophic break-off event. These new precursory signs seem to be generally valid as they were observed during both 1965 and 2000 Allalingletscher break-off events and in the break-offs of both the Glacier du Tour in 1949 and the Feegletscher in 2009. In a more general context, climate change may affect the stability of steep glacier tongues as they retreat and may evolve towards a critical geometry. This model casts a gleam of hope for a better understanding of the ultimate rupture processes resulting from such sliding instabilities.
Acknowledgements. This work was partly funded by the European Union seventh framework programs (EU-FP7) project Assessing Climate impacts on the Quantity and quality of WAter (ACQWA; grant 212250). We are grateful to Kraftwerke Mattmark for supporting the long-term monitoring program of Allalingletscher and to Hermann Bösch for processing the DEMs for Allalingletscher. Useful comments of the reviewers helped to improve the clarity of the manuscript.

Edited by: J. M. Vilaplana

Reviewed by: J. Bordonau and W. Haeberli

\section{References}

Alean, J.: Ice avalanches: some empirical information about their formation and reach, J. Glaciol., 31, 324-333, 1985.

Bell, R. E.: The role of subglacial water in ice-sheet mass balance, Nature Geosci., 1, 297-304, 2008.

Boulton, G. S., Lunn, R., Vidstrand, P., and Zatsepin, S.: Subglacial drainage by groundwater-channel coupling, and the origin of esker systems: Part 1-glaciological observations, Quaternary Sci. Rev., 26, 1067-1090, 2007.

Dieterich, J. H.: A constitutive law for rate of earthquake production and its application to earthquake clustering, J. Geophys. Res., 99, 2601-2618, 1994.

Faillettaz, J., Pralong, A., Funk, M., and Deichmann, N.: Evidence of log-periodic oscillations and increasing icequake activity during the breaking-off of large ice masses, J. Glaciol., 57, 725-737, 2008 .

Faillettaz, J., Sornette, D., and Funk, M.: Gravity-driven instabilities: interplay between state-and-velocity dependent frictional sliding and stress corrosion damage cracking, J. Geophys. Res., 115, B03409, doi:10.1029/2009JB006512, 2010.

Faillettaz, J., Funk, M., and Sornette, D.: Icequakes coupled with surface displacements for predicting glacier break-off, J. Glaciol., 57, 453-460, 2011a.

Faillettaz, J., Sornette, D., and Funk, M.: Numerical modeling of a gravity-driven instability of a cold hanging glacier: reanalysis of the 1895 break-off of Altelsgletscher, Switzerland, J. Glaciol., 57, 817-831, 2011b.

Farinotti, D., Usselmann, S., Huss, M., Bauder, A., and Funk, M.: Runoff evolution in the Swiss Alps: Projections for selected highalpine catchments based on ENSEMBLES scenarios, Hydrol. Process., accepted, doi:10.1002/hyp.8276, 2011.

Flowers, G. E. and Clarke, G. K. C.: Surface and bed topography of Trapidge Glacier, Yukon Territory, Canada: digital elevation models and derived hydraulic geometry, J. Glaciol., 45, 165-174, 1999.

Glaister, R. M.: The ice slide on the Glacier du Tour J. Glaciol., 1, 508-509, 1951.

Huggel, C., Haeberli, W., Kääb , A., Bieri, D., and Richardson, S.: Assessment procedures for glacial hazards in the Swiss Alps, Can. Geotech. J., 41, 1068-1083, 2004.

Huss, M., Hock, R., Bauder, A., and Funk, M.: 100-year mass changes in the Swiss Alps linked to the Atlantic Multidecadal Oscillation, Geophys. Res. Lett., 37, L10501, doi:10.1029/2010GL042616, 2010.

Jay-Allemand, M., Gillet-Chaulet, F., Gagliardini, O., and Nodet, M.: Investigating changes in basal conditions of Variegated 
Glacier prior to and during its 1982-1983 surge, The Cryosphere, 5, 659-672, doi:10.5194/tc-5-659-2011, 2011.

Pralong, A. and Funk, M.: On the instability of avalanching glaciers, J. Glaciol., 52, 31-48, 2006.

Röthlisberger, H.: Eislawinen und Ausbrüche von Gletscherseen, in: Gletscher und Klima - glaciers et climat, Jahrbuch der Schweizerischen Naturforschenden Gesellschaft, edited by: Kasser, P., wissenschaftlicher Teil 1978, 170-212, Birkhäuser Verlag Basel, Boston, Stuttgart, 1981.

Röthlisberger, H. and Kasser, P.: The readvance of the Allalingletscher after the ice avalanche of 1965, Materialy Glyatsiologicheskikh Issledovaniy, Khronika Obsuzhdeniya, 33, 152164, 1978.
Schwanghart, W. and Kuhn, N. J.: TopoToolbox: A set of Matlab functions for topographic analysis, Environ. Modell. Softw., 25, 770-781, 2010.

Schweizer, J. and Iken, A.: The role of bed separation and friction in sliding over an undeformable bed, J. Glaciol., 38, 77-92, 1992.

Sidle, R. C. and Ochiai, H.: Landslides: Processes, Prediction, and Land Use, Water Resour. Monogr. Ser., 18, 312 pp., AGU, Washington, D.C., doi:10.1029/WM018, 2006. 